Article

\title{
Divine Love as the Reason for Creation in Islam-An Exploration of Nursi's Epistles of Light
}

\author{
Nasrin Rouzati ${ }^{1,2}$ \\ 1 International Foundation for Muslim Theology, Basingstoke RG24 9FX, UK \\ 2 Religious Studies Department, Manhattan College, Riverdale, NY 10471, USA; \\ nasrin.rouzati@manhattan.edu
}

Received: 9 November 2020; Accepted: 7 December 2020; Published: 13 December 2020

check for updates

\begin{abstract}
This paper aims to answer the question "why did God create the world" by examining Bediuzzaman Said Nursi's magnum opus, the The Epistles of Light (Risale-i Nur), to demonstrate that, from a Nursian perspective, divine love is the raison d'etre for the creation of the world. The first section will investigate the notion of divine love as reflected in the wider Muslim scholarly literature. This will be followed by a discussion on the theology of divine names, with special attention to Nursi's perspective, illustrating the critical role that this concept plays in Nursian theology particularly as it relates to cosmic creation. The third section will explore the metaphysics of love, the important implications of God's love in the creation of the world, and its role as the driving force for the dynamism and activities within the structure of the universe. The Qur'anic presentation of love, mahabba, as well as the significance of the reciprocal nature of love between God and humankind will be explored next. The final section will shed light on the synergy between divine love and the Qur'anic notion of $i b t i l \bar{a}$, trial and tribulation, to demonstrate its instrumentality in man's spiritual journey.
\end{abstract}

Keywords: Islam; creation; divine love; Nursi; Islamic theology; Ghazālī; Ibn Sīnā; Risale-i Nur

\section{Introduction}

Throughout Muslim intellectual history, the Qur'an, the revealed text and the foundation stone of the religion of Islam, has been considered the highest and the most influential source of Islamic scholarship. One of the central pillars of the Qur'anic teaching and worldview is the creation of the universe, all that is other than God, and the attributes of the One Who willed to bring the world into existence. Consequently, efforts to understand the creation of the cosmos, as well as the attributes of its Creator, constitute a major portion of Muslim philosophical, theological, and mystical literature. Inquiries regarding existence (wujūd), non-existence ('adam), whether the world is eternal (qadīm) or created in time (hâadith), and contingency (imkān), sprang from critical questions about what creation is and how it occurred. Still, Muslim thinkers who incorporated philosophy and mysticism in their worldview as well as the protagonists of the mystical dimension of Islam, focused their attention on the question, why did God create the world? What is the wisdom behind creation?

This paper aims to answer the above question by examining Bediuzzaman Said Nursi's magnum opus, the Risale-i Nur ('The Epistles of Light'), to demonstrate that, from a Nursian perspective, divine love is the raison d'etre for the creation of the world. ${ }^{1}$ The first section will investigate the notion of

1 Bediuzzaman Said Nursi (1877-1960), was a distinguished scholar from Eastern Anatolia whose magnum opus, the six thousand-page exegesis of the Quran entitled The Epistles of Light (Risale-i Nur) is arguably the most significant theological work to come out of Turkey in the past five hundred years. A madrasa-trained scholar with roots in the Muslim mystical tradition, Nursi was something of a Muslim polymath, with experience and expertise in the full range of scriptural and intellectual sciences. Drawing inspiration from figures such as Abd al-Qadir Jilani and Shaykh Ahmad Sirhindi, Nursi 
divine love as reflected in the wider Muslim scholarly literature. This will be followed by a discussion on the theology of divine names, with special attention to Nursi's perspective, illustrating the critical role that this concept plays in Nursian theology particularly as it relates to cosmic creation. The third section will explore the metaphysics of love, the important implications of God's love in the creation of the world, and its role as the driving force for the dynamism and activities within the structure of the universe. The Qur'anic presentation of love, mahabba, as well as the significance of the reciprocal nature of love between God and humankind, will be explored next. The final section will shed light on the synergy between divine love and the Qur'anic notion of ibtilā, trial and tribulation, to demonstrate its instrumentality in man's spiritual journey.

\section{Doctrine of Divine Love in Muslim Thought}

The notion of divine love has presented itself in the Muslim philosophical, theological, and mystical discourses, albeit in various, and at times, paradoxical dimensions throughout Muslim intellectual history. From the perspectives of the philosophers (falsifa), the concept was intertwined with the ontological and cosmological disposition of the universe and the Creator-creation relationship. ${ }^{2}$ A prime example of such a work is seen in the writings of the most influential and prominent Muslim philosopher, Ibn Sīnā (Avicenna, d. 428/1037), known as the 'philosopher of being' par excellence. The concept of creation is explained by Ibn Sinnā in the context of his emanation theory. ${ }^{3}$ In Avicennan philosophy, the cosmos is generated through a hierarchical progression consisting of ten intellects that spring from each other and ultimately from the Necessary Being, (wājīb al wujūd). On the ontological level, God is described as the "Necessary Existent who is above perfection because not only does He have the existence that belongs only to Him, but every other existence also is an overflow of His existence and emanates from Him." (Avicenna 2005, p. 283). In Ibn Sīnā's philosophy, while God is simultaneously the only Necessary Being and transcendent, He is pure Intellect, pure Good, and pure Love; indeed, these attributes are part of His essence which flow and emanate to other beings (Ibid., p. 284).

Ibn Sīnā's most elaborative account on the doctrine of divine love appears in his Risālah fí al-'Ishq, Treatise on Love (Avicenna 1945, pp. 208-28). Establishing the concept in the overall emanative theory of being, Ibn Sinna identifies love as the perpetual force within the emanating structure of the universe. Since God is Pure Good, "it is a necessary outcome of His wisdom (hikma) and the excellence of His governance to plant into everything the general principle of love." (Ibid., p. 212). Insofar as the pervading power of love is concerned, Ibn Sīnā affirms, "the never-ceasing existence of this love in all begins determined by a design is, therefore, a necessity ... the existence of every being determined by a design is invariably accompanied by an inborn love." (Ibid., p. 213). Likewise, Ibn Sīnā asserts that love is the source of human beings yearning towards perfection, and the reason why they strive to return to the First Principal (al-Mabdā 'al-Awwal). ${ }^{4}$

Sadr al-Din Shirāzī (1571-1636), known as Mullā Sadrā, who has had a significant influence in shaping Muslim philosophical thought, also expounds upon the notion of divine love in the creational structure of universe. As Rahman points out, Sadrā's unique approach to philosophy, where intellectual and rational investigation is waved into theological reflections and is grounded in intuitive realization

considered his life's work to be the revival and consolidation of the belief of the masses following the fall of the Ottoman Empire and the establishment of the Turkish Republic, with what he believed were its dangerous secularizing objectives. Nursi's teachings led to the formation of a text-based faith movement known as the Nur Community, which has in excess of ten million adherents worldwide. For an excellent biography on Nursi, (see Vahide and Ibrahim M. 2005).

2 The first systematic Muslim philosophical reflection on divine love, Fi-māhiyyat-al- 'Ishq, On the Quiddity of Passion, was composed by a group of tenth-century philosophers called Ikhwān al-Șafā (Brethren of Purity). For a partial English translation and commentary, (see Chittick 2013, pp. 280-83; also see Abrahamov 2003, pp. 18-21).

3 For more on Ibn Sinnā's philosophy and his influence on philosophical thought both in the East and the West (see Nasr 2006, pp. 141-42).

4 For more on this, see (Anwar 2003, pp. 331-45). Also see (Netton 1994, pp. 156-57). 
of the truth, posits him as one of the most sophisticated philosophers in the entire history of Islamic Philosophy (Rahman 1975, pp. 13-20). Sadrā's magnum opus, al-Asfār al-Arb'a, provides an extensive elucidation on the metaphysics of being, Unity of Existence (Wahdat al-Wujūd), and God and His attributes. In his philosophy, God is the sole Necessary Being — the absolute Good and the absolute Perfect-while all other beings lack a certain degree of perfection. In Sadriān thought, divine love is the very reason the universe is functional; indeed, if it were not for love, the creation of the cosmos (hudūth) would not have been possible (Mulla Sadra Shirazi 1388, vol. 3, pp. 178-80).

As for the Muslim theologians (mutakallimun), the idea that God's relationship with his creation, more specifically with humankind, might be of a love relationsship, met with serious opposition by Ash'arite and $\mathrm{Mu}^{\prime}$ tazilite schools of Kalām both dogmatic as well as scholastic. The root of this objection seems to have been theologians' persistence on God's absolute transcendence, while restricting His immanency to creation including humankind. The concept of a mutual love relationship between the Creator and created seemed inappropriate and highly contradictory. Hence, with reference to God's love for humankind, the Ash'arite theologian al-Juwaynī (d.1085) explicates two points: firstly, God's love for man lies in His bestowment of favors to him, and secondly, His love is only explainable through His Will (Al-Juwayni 2000, p. 130). As Bell observes, this view was opposed by Ibn Taymiya (d.1328), famous Hanbalite theologian, on the grounds that according to orthodox view, while God wills everything-including disagreeable and evil things-He does not love them. Moreover, for Ibn Taymìya, equation of God's love with His will is identical to denying God of one of His attributes (Bell 1979, p. 47).

On the notion of love between God and man, the Mu'tazilite theologians expressed an opinion similar to their Ash'arite counterparts. For example, the distinguished Mu'tazilite exegete, Abu al-Qadīm al-Zamakhshari (d.1144), in his exposition of the Qur'anic narrative, God Loves them and they love Him ${ }^{5}$, informs his audience that love for God means 'obedience' to Him, to strive to please Him, to gain His approval, and in not behaving in ways that results in His wrath and punishment. On the other hand, Zamakhshari asserts that the implication of God's love for humankind-His servants-is that He grants them the best rewards for their obedience, is pleased with them, and elevates their status in the hereafter (Zamakhshari 1389, vol. 1, p. 797).

Aside from efforts to avoid anthropomorphic interpretations of Qur'anic portrayals of God, the mutakallimun generally avoided symbolism and allegorical interpretation of the Qur'an. Their lack of attention to the imagery and symbolism of the sQur'an is one of the main divergences between the theologians and the mystics. According tso Chittick, Ibn al-'Arabī (1165-1240), the prominent Andalusian Sufi and spiritual authority of Islam, criticizes theologians' interpretation of the Qur'an, who, for the most part, engaged with the apparent meaning of the Qur'anic verses. Ibn al-'Arabi's counsel to them is "to open up their souls to God's disclosure of Himself in forms and symbols" (Chittick 2013, pp. 3-5). ${ }^{6}$

The idea of God and man having a loving relationship, after an initial disagreement amongst the early Sufi's, developed to a full doctrine and became one of the main pillars in the practice of Sufi Islam. The famous Sufi woman, Rābi'a al-'Adawiyya (d. 801), is one of the first mystics who was instrumental in the development of the theology of love. As Schimmel points out, it was Rābi'a, who, by asserting that love comes from Eternity and embraces the whole creation, established a strong foundation for a mutual love relationship between the divine reality and human reality, and paved the way for later Sufis (Schimmel 1975, pp. 39-40). The historical development of love theory in Sufism is extensively discussed in Kitāb 'atf al-alif al-ma'lūf'alā al-lām al-ma'țūf written by Muhammad al-Daylamī of late tenth century. In addition to his own contributions, al-Daylamī provides an anthology of the opinions of philosophers, theologians, and mystics on divine love (Abrahamov 2003, p. 36).

5 The Qur'an, 5:54.

6 For more on Ibn al-'Arabī and the relation between rational thought and imagination, (see Chittick 1989). 
The first philosophical theologian and mystic who successfully developed the doctrine of divine love is Abū Hāmid al-Ghazālī (1058/1111), the eminent Muslim intellectual of fifth-century Islam. According to Ormsby, Ghazālī's effort in development of the doctrine of divine love in a systematic manner and with rational argumentation based on tradition, not only answered the objections of theologians, but also established a strong foundation for love of God to appear as a reputable discourse. ${ }^{7}$

Said Nursi's magnum opus, the Risale-i Nur, provides some of the most elaborated expositions on the notion of love from a theosophical perspective. Although Ash'arite in his theological affiliation, as it will be shown later, Nursi paints a very different portrait of divine love, and invites his audience to ponder about the reality of love and its implications.

\section{Creation and Theology of Divine Names}

If the creation of the universe, and the multiplicity of forms that appear in it, are interpreted from a theistic perspective, 'creation' may be defined as God's Acts, and therefore, the focal point of all revealed scriptures. Accordingly, while God's essence ( $d h \bar{a} t)$ is not discussed in the Qur'an and Muslim

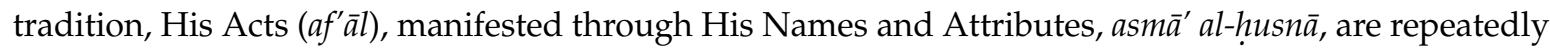
emphasized. At the center of the Qur'anic teaching is, of course, divine unity, tawhīd, which is often referred to as the fountainhead of Islam.

In Nursian cosmology, the universe is the stage where all of the divine names and Attributes are made to manifest in various degrees:

The realities of all beings and of the universe are based on the divine names. Each being's reality is based on one Name or on many. The attributes of things and the arts they display are also based on and rely upon a name. True natural science is based on the name of All-Wise, true medicine on the name of Healer, and geometry on the name of Determiner, and so on. In the same way that all the science is based on and come to an end in a name, the realities of all arts and science, and of all human attainments, are based on the divine names. (Nursi 1992a, p. 655)

Nursi's exposition on the centrality of the divine names, acting as the pillar which the entire universe depends on, stems from the fact that in his theology the cosmos is created perfectly by the creative power of the Perfect Creator. It may be pointed out here that Jalāl al-Dīn Rūmī (1207-1273), one of the most influential Muslim mystics and Sufis, seems to be in agreement with Nursi when he says:" Know that the world of created beings is like pure and limpid water in which the attributes of the Almighty are shinning. The whole sum of pictured forms is a mere reflection in the water of the river: when you rub your eye, you will realize that all of them are really He (Rūmī [1926] 2001, pp. 3172, 3183).

In the thought of al-Ghazālī, whom Nursi quoted often in the Risale-i Nur, this world, where man with all his limitations is able to 'reach' God and be in union with Him is indeed the best that it can be, "there is not in possibility anything more wonderful than what is" (laysa fi'l-imkān abda' mimmā kān) (Al-Ghazālī 1377, vol. 4, p. 445). ${ }^{8}$ Nursi expands on al-Ghazālī's dictum to elucidate on the overarching excellence of the world and its dependency on, and connection to, the divine names:

The Necessarily Existent One possesses infinite beauty and perfection, for all the varieties of them dispersed through the universe are the signs and indications of His beauty and perfection. Those who possess beauty and perfection clearly love them. Similarly, the All-Glorious One greatly loves His beauty, and He loves it in a way that befits Himself. Furthermore, He loves His names, which are the rays of His beauty, and since He loves them, He surely loves

7 See preface to Al-Ghazālī (2011).

8 It should be mentioned that several centuries later this statement became the focal point of Leibnitz's theodicy. For an excellent discussion on al-Ghazālī's dictum, see (Ormsby 1984). 
His art, which displays their beauty. In which case, He also loves His creatures, which are mirrors reflecting His beauty and perfection. Since He loves the creatures that display them, He certainly loves the creatures' fine qualities, which point to the beauty and perfection of His names. (Nursi 1992b, p. 353)

Closely related to the concept of God in the Qur'an is the relationship of God to His creation, particularly man, who has been positioned on earth to become God's vicegerent (khalifa). ${ }^{9}$ The task for man is to gain knowledge of God, begin to observe the universe in the light of His signs (āya t), and to make a serious effort to act in ways that accord with the responsibility of the Trust (amanna). ${ }^{10}$ The Qur'anic emphasis on the significance of the intimate relationship between God and man, has served as the wellspring of inspiration for many great Muslim thinkers, such as Ibn Sina and al-Ghazālī, who have established paths to illustrate the extent by which humankind is able to shape an utterly close connection with his Lord. ${ }^{11}$

For Nursi, since the divine names are the means by which God makes Himself known, likewise, humankind is asked to get to know the Creator through His names. Reaffirming the significance of the divine names as well as man's critical role in becoming who he is, Nursi reminds his audience that mankind is the fruit of the creational tree, and the mirror held up to the most beautiful names of God, capable of reflecting His Names fully and comprehensively:

Now the true meaning of your life is this: it is acting as a mirror to the manifestation of divine oneness and the manifestation of the eternally Besought One. That is to say, through comprehensiveness as though being the point of focus for all the divine names manifested in the world, it is its being a mirror to the Single and eternally Besought One. (Nursi 1992a, pp. 139-41)

That man has been given the necessary tools to embark on this spiritual journey is clear from Nursi's exposition on the notion of an $\bar{a}$, the human 'I'. From Nursi's perspective, an $\bar{a}$, the self-that aspect within human soul which constitutes its individuality and distinction from all others-must be viewed as a unit of measurement through which he becomes aware of the Source of all that the self attributes to itself. Once man acknowledges, Nursi asserts, that the sense of ownership exercised by the self is illusionary, and that in actuality, the true ownership belongs to the One Who is the ultimate Source of Being, he begins to climb the ladder of self-knowledge (ma'rifat al-nafs) which ultimately leads to God-knowledge (ma'rifat al-Allah). Viewed in this light, it is through ana that the samples of the names and attributes have been granted to man as a unit of measurement-the sole purpose of which is to point to their true Source:

Just as the ' $\mathrm{I}$ ' is the key to the divine names, which are hidden treasures, so is it the key to the locked talisman of creation; it is a problem-solving riddle, a wondrous talisman. When its nature is known, both the ' $\mathrm{I}$ ' itself, that strange riddle, that amazing talisman, is disclosed, and it discloses the talisman of the universe and the treasures of the necessary world. The key to the world is in the hand of man and is attached to his self. For while being apparently open, the doors of the universe are in fact closed. God Almighty has given to man by way of a Trust, such a key, called the ' $I$ ', that it opens all the doors of the world; He has given him an enigmatic ' $\mathrm{I}$ ' with which he may discover the hidden treasures of the Creator of the universe. (Ibid., p. 558)

In Nursi's worldview, everything that the human self, the " $\mathrm{I}$ ", seems to possess-knowledge, compassion, wealth, power, beauty, etc.-is 'other indicative' (ma'ān $\bar{\imath}$ harfì). Hence, the infinite diversity

9 The Quran, 2:30.

10 The Quran, 33:72.

11 For a discussion on various approaches adopted by Muslim intellectuals in building relationship with God, see (Elkaisy-Friemuth 2006). 
that appears in the universe are ways by which man is able to understand the names $\left(a s m \bar{a}^{\prime}\right)$ and attributes (sifät) of the Creator, while concurrently acknowledging that God is, in reality, other than what is observed from the created beings. Nursi's exposition is, of course, rooted in the broader theological discourse that stems from the first pillar of Islam, the shahāda (kalimat al-tawhind): "there is no god, but God and that Muhammad is God's messenger". Although, according to the experts in jurisprudence, this simple pronouncement recognizes a person as a Muslim, its actualization entails a deeper understanding of its meaning, as well as a conscious commitment to its application. In the context of tawhì d, then, Nursi's notion of human ' $\mathrm{I}$ ' is instrumental in assisting man to know himself through the samples of the names and attributes, and to recognize that, indeed, there is no true possessor of knowledge except the Omniscient, no true power but the Omnipotent, no true compassion but the Compassionate, and no true beauty except the Beautiful. ${ }^{12}$

As it relates to the doctrine of divine love, the theological and mystical discourse is constructed upon the Qur'anic depiction of God through His name of al-Wadiud, the All Loving; situating the name in the context of tawhi $\bar{d}$, it means: there is nothing truly loving except the Loving. According to

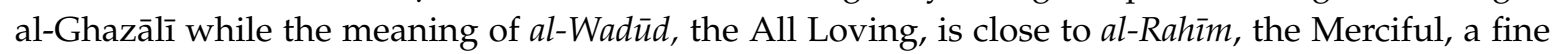
distinction is embedded between the two.

Mercy is linked with one who receives mercy, and the one who receives the mercy is needy and poor. So, the actions of the Merciful presuppose there being one who is weak to receive mercy, while the actions of the Loving-Kind do not require that. Rather, bestowing favors from the outset results from loving-kindness. (Al-Ghazālī 1992, p. 118)

In Nursian worldview and theology, the divine name of al-Wadī is manifested through boundless activities and transformations that are visible within the structure of the universe-indeed; love is what energizes the world.

Just as a great many degrees of loveliness, beauty, grace and perfection are present in all of the divine names, so there are a great many degrees of love, pride, glory and grandeur. It is because of this that the elevated and authoritative saints who manifested the Name of $a l-W a d \bar{u} d$, the Loving One, said: 'Love is the very leaven of the universe. It is through love that all beings are in motion. It is from love that laws of attraction, affinity and ecstasy present in all beings spring.' (Nursi 1992a, p. 652)

It is worth mentioning here that while Nursi is not considered a philosopher, his theological reflections on divine names and their manifestations on the cosmic plane resemble some of Ibn Sīnā's philosophical expositions on the attributes of the Necessary Being as the Source of beauty, goodness, and love. One may argue, therefore, that the mystical tendency in Ibn Sīnā's philosophy presented in his magnum opus, The Metaphysics of Healing (al-Shifä'), is perhaps the common ground between the two thinkers. ${ }^{13}$

\section{Divine Love: The Initiating Source for Creation}

As we have already discussed, from the perspectives of the early Kalām experts, the notion of a loving relationship between the Creator and humankind was perceived as a clear sign of deviation from the path of orthodoxy set by the theological schools. Although certain aspects of God's attributes-knowledge, power, will, etc.-constituted a major portion of the teachings of the dialectical theologians (mutakallimun), God's love, however, did not appear at the core of their debates. Therefore, the early kalām experts dedicated their efforts on the necessity of following the religious command:

12 For an excellent discussion on Tawhīd and its implications, see (Chittick 1994, chp. 3).

13 For instance, Ibn Sīnā's discussion on the notion of tajallī is similar to Nursi's passage mentioned above. See (Avicenna 2005, Book 9, chp. 3). 
God's love is displayed in the religious command since it leads to salvation, and man's love for God is in their obedience to that command. ${ }^{14}$

Al-Ghazālī, as alluded to before, is recognized as the first theologian who successfully theorized the doctrine of divine love by establishing it in a firm foundation rooted in the teachings of the Qur'an and tradition of the Prophet. His comprehensive exposition of love is presented in Book 36 of the Ihyā' 'ulüm al-din: Kitāb al-mahabba wa'l-shawq wa'l-uns wa'l-ridā, Love, Longing Intimacy and Contentment (Al-Ghazālī 2011). In Ghazāliān theory, "God has no view of anything other than Himself as being other than Himself. On the contrary He only sees His own essence and His own acts exclusively since nothing exists except His essence and acts ... in this way therefore He loves only Himself." (Al-Ghazāli 2011, pp. 101-2).s Al-Ghazālī draws attention to the Prophetic tradition which makes love of God a condition of faith (īmann), and criticizes the theologians who equate man's love for God to mean obedience: "How might love be glossed as obedience, seeing that obedience is one of the results and effects of love?" (Ibid., p. 5)

Al-Ghazāli objects to those scholars who claim that the love relationship is only possible between the like and the like, asserting that "when they deny love, they also deny intimacy and longing and the pleasure of secret colloquies (munājāt)." (Ibid., p. 2). As we saw earlier, humankind's longing for God, as the Source of Pure Perfection, is also discussed in Ibn Sīnā's Treatise on Love, Risālah fĩ al-'Ishq. The Necessary Existent, Ibn Sīnā asserts, is the Source of absolute perfection, and since human beings lack this high level of perfection, it follows that, through the inborn love ingrained in their makeup, they yearn the Source of that pure goodness and perfection (Avicenna 1945, pp. 213-14).

Aḥmad Al-Ghazālī (d. 1126), the younger brother of Abū Hāmid, goes much further in his analysis of divine love. Although overshadowed by the recognition and accomplishments of his older brother, Ahmad Al-Ghazālī is mostly known for his contributions in the mystical literature. In his major work called the Sawānih, Inspirations, he positions divine love at the center of metaphysics, and unveils the whole of creation in relation to it-for him, love is the divine essence Itself. Although the main theme of the Sawānih revolves around the metaphysical expositions of Love, and despite one's expectation, Aḥmad Al-Ghazālī does not begin the book by discussing love itself; rather, he begins by drawing attention to the journey between love and spirit and the relationship between them. It is later in the book that we are told, love is a bird whose nest is in Eternity (qidam) (Al-Ghazāli 2013, p. 85). As observed by Lumbard, "to view 'love' as the divine essence is thus to understand it as the very nature of God beyond the divine names and attributes ... to claim that one can have some realization of the divine essence in Itself through love would then be seen by many as a radical claim that challenges the boundaries of orthodoxy." (Lumbard 2016, pp. 112-14).

In Aḥmad Al-Ghazālī's worldview, the relationship between God and humankind may be understood from both the ontological and the soteriological characteristics of love. The ontological feature is encapsulated in the famous hādith qudsī known as "Hadith of the Hidden Treasure" in which God reveals His reason for the creation of the universe: "I was a hidden treasure, and I loved to be known, so I created the world". ${ }^{15}$ Love, therefore, is the essence of the Creator and the substance from which everything is plaited. The soteriological aspect of love is revealed in the Qur'anic verse referenced before, "He loves them and they love Him". For Ahmad Al-Ghazālī, the climax of the interplay of love is when the seeker, the lover, "will realize his true identity as a locus for the beloved's love of himself ... the derivation of the lover and the beloved is from Love." (Lumbard 2016, p. 115).

Although this is not a comparative study, it may be worth mentioning that a similar view is expressed by Emanuel Swedenborg (d.1772), the distinguished Swedish Christian theologian and philosopher: "God alone—the Lord—is love itself, because He is life itself. The true divine essence

14 For more on this, see (Chittick 2013, p. 279).

15 This kind of hädith refers to God speaking to the Prophet but the content of which does not appear in the Qur'an. It should be noted that while the majority of Muslim scholars do not regard this particular hāadith as having a strong chain of narrators, they accept the spiritual message that it contains. For more on this, see (Brown 2009, pp. 193-95). 
is love." (Swedenborg 2015, pp. 2, 11, 13). Similarly, Thomas Jay Oord, a contemporary Christian theologian, is of the opinion that Love is an overarching notion encompassing the rest of divine attributes, to the point that is beyond God's control; His love is in fact "uncontrolled". In discussing God's nature and attributes, Oord claims that conceptually and logically Love comes first; all other attributes of God need to be reformulated in ways that are in harmony with Love. In other words, "God's love is a necessary and eternal attribute of God's nature." (Oord 2015, p. 161). In an effort to clarify his claim, Oord compares his central idea with other Christian theologians:

For instance, some theologians assume power or sovereignty comes first in God. Consequently, they say God has the power not to love. To put it another way, because they believe God's sovereign will comes first, God can choose not to love. By contrast, I think love logically comes before power in God. Among other things, this means I do not think God can choose not to love. Because love comes in God's nature logically before choice, God must love. God is free to choose how to love but not free to choose whether to love. (Baker 2017, pp. 4-5)

Returning to the concept of love in Muslim theological thought, we notice that "The Hidden Treasure Hadith", mentioned above, becomes perceptible in Nursi's Risale-i Nur on multiple occasions. Nursi makes use of this hădith to develop his arguments about the instrumentality of love pertaining to divine purpose for the creation of the cosmos. In Nursian theology, divine love is indeed the reason d'etre for the creation of the universe.

Love is the cause of the universe's existence, and what binds it; and it is both the light of the universe and its life. Since man is the most comprehensive fruit of the universe, a love that will conquer the universe has been included in his heart, the seed of that fruit. Thus, the only one possession infinite perfection may be worthy of such an infinite love. (Nursi 1992a, p. 367)

Applied in the context of tawhid, and viewed in conjunction with his theological reflections on divine attribute of $a l$-Wad̄ $\bar{d}$ (All Loving), Nursi's statement draws attention to two related concepts. Firstly, the creation of the universe is through the manifestation of divine love, and secondly, God is the only true object of love-there is nothing truly loving except the Loving. In Rūmī's word, "all creatures are set in motion by Love. Know that Love's branches are in eternity without beginning, its roots in eternity without end; God is Love and beyond Love." (Rūmī 1379, pp. 4183, 5001).

The prominent Qur'anic exegete, Rashīd al-Dīn Maybudī (520/1126), who is known for his esoteric commentary, tafsir, of the Qur'an, seems to be in convergence with Nursi on the centrality of the notion of love within the creational structure of the world. In his major exegetical work, Kashf al-asrār wa 'uddat al-abrār (Unveiling of Mysteries and Provision of the Righteous), Maybudī identifies knowledge and love to be the driving force behind the creative act of God. However, in the context of creation of man, superiority is given to love as he elucidates on the Qur'anic verse: "We created you from a single soul"16.

He created Adam and humanity to be the storehouse of His eternal secrets and the target for His generous favors. 'I was a hidden treasure and I wished to be known'. I had essence and attributes, transcendent, a knower was needed. I had majesty and beauty unending, a lover was needed. Other creatures had nothing to do with love, for they did not have that lofty aspiration. ${ }^{17}$ (Maybudī 1371, vol. VIII, p. 387)

It may be noted here that while the notion of love makes itself known in various sections of Maybudi's exegesis, he, nevertheless, attempts to preclude any theological misunderstanding for

16 The Qur'an, 39:6.

17 The English translation is from (Keeler 2006, p. 132). 
the statement above - that God is in need of man to know and love Him-by reminding his readers on God's Omnipotence: "It was possible, i.e., theologically allowable, for Him to create a hundred thousand like us in an instant, but the secret of that unfathomable love was exclusively meant for us" (Keeler 2006, p. 133).

If divine love is the reason for the existence of the cosmos, as Nursi states, what can be said for all the activities, motions and transformations that are observed in the world? Responding to this question, Nursi informs us that divine love is indeed the empowering energy that makes possible all activities and changes:

Just as the activity of creatures arises from appetite, desire, and pleasure, and there is a definite pleasure in all activity; indeed, all activity is a sort of pleasure; so too, in a suitable way and form appropriate to His essential self-sufficiency and absolute riches and in a manner fitting for His absolute perfection, the Necessarily Existent One has boundless sacred compassion and infinite holy love. And He feels a boundless sacred holy joy arising from that sacred ardor, and, if one may say so, an infinite sacred pleasure arising from the sacred joy. And pertaining to that Merciful and Compassionate One, is, if the term is permissible, a boundless sacred gratification and infinite holy pride arising from the boundless feeling of compassion that springs from the sacred pleasure, sacred gratification and pride which arise from the gratitude and perfections of creatures which result from their abilities emerging from the potential to the actual and their developing within the active of power. It is these which necessitate in boundless fashion, and endless activity. (Nursi 1992b, p. 111)

As it may be seen from the above passage, Nursi's engagement with the notion of divine love-as the main cause for the creation, as well as the driving force for the infinite activities visible in the world—stems from his overall teleological worldview that underpins the Risale-i Nur.

\section{Reciprocal Love between God and Humankind}

As we saw earlier, al-Ghazālī affirmed that this world is indeed 'the best of all possible worlds', and Nursi asserted that divine love is the reason for the creation as well as the force that energizes the universe. But the question that still remains is how divine love, which is intertwined with the fabric of this universe and more notably in man's life, may serve as the bridge between the divine reality and the human reality, between the transcendent God and man who is the goal of the creation to begin with. As Jalāl al-Dīn Rūmī states in his Mathnawī: the only reason that the gardener plants a tree is for the sake of the fruit. Man is the goal of the creation; he is the last creature that comes into existence; yet, in reality, he is the first (Rūmī 1957, vol. III, pp. 1128-29).

Recapitulating the meaning of the Qur'anic verse: "God loves them, and they love God"18, we know that the story of love begins with God in eternity, i.e., love has no beginning. This understanding is, of course, in accordance with the overall epistemology of the Qur'an: human situation begins before time with the Covenant of Alast and the bestowal of the trust, enters into time with man's temporal creation, and over the course of time it is returned to its original home.

That there was a time before time when God made a covenant with humankind is clear from the following verse: "When your Lord took out the offspring from the loins of the Children of Adam and made them bear witness about themselves. 'Am I not your Lord?' They replied, 'Yes, indeed we bear witness.'"19 Although Qur'anic exegetes offered various interpretations, for the most part, there seems to be convergence amongst Muslim scholars with reference to the Alast agreement. For example, the eminent Qur'anic exegete, Allāmeh Muhammad Husain Tabātabā'i (d. 1982), informs us that this symbolic contract was signed when we were in proximity with God, having not yet been

18 The Qur'an, 5:54.

19 The Quran, 7:172. 
created in form or physical being-man's state in 'pre-existence' (Tabatabai 1367, vol. 8, pp. 400-21). Similar elucidation, albeit in a more mystical language is given by Maybudī, who posits love at the foundation of human existence: "This verse alludes to the biding of a covenant of love in the era of the Beginningless, when the Real was present and the Reality was there; the foundation of love was made then." (Maybudī 1371, vol. VIII, pp. 793-96) ${ }^{20}$

The primordial covenant is frequently understood in conjunction with the Qur'anic verse about the Trust, the amāna: "We offered the Trust to the heavens, the earth, and the mountains, yet they refused to undertake it and were afraid of it; mankind undertook it - they have always been very inept and rash." 21 The classical Qur'anic exegeses offer various interpretations on what precisely is the amāna such as: adherence to religious commands stated in Islamic law, the intellect, belief in the Oneness of God, knowing God, and free will (lkktiār) (see Tabatabai 1367 Solar: Vol:16, 524-531). In Nursi's theology, the Trust is interpreted as man's potential to become God's vicegerent on earth. As Turner explains, "Nursi is not alone in defining the 'trust' as man's God given ability to act as God's vicegerent; in accepting the 'trust', man takes it upon himself to act as God's 'representative' on earth." (Turner 2013, p. 177). In the mystical exegesis of Maybudī, the Trust is interpreted as love, which has been ingrained in the makeup of man: "He brought a handful of dust into existence and burned it with the fire of love." (Maybudī 1371, vol. 8, pp. 100-2). Viewed in this light, love, then, may be explained as the motivating force, as Nursi elucidated before, for man to act as God's vicegerent by becoming the mirror in which all God's attributes are made to manifest in the most comprehensive manner.

If love begins with God in eternity, and the seed of divine love is planted in humankind's innermost nature, it follows that human beings do indeed love God; nonetheless, they may not be aware of it. Therefore, the reciprocal love between the divine entity and human entity is perhaps the most important constituent of man's life-the component that is instrumental in the actualization of his potentialities, which results in increase knowledge of the Creator, as well as the nurturing of the loving relationship with the Beloved Creator. According to al-Ghazālī, while it is true that from the metaphysical perspective God causes man to love him, mankind, nonetheless, must actively partake in this journey by consciously and purposefully reflect on his own impotence and dependency on God's infinite love. ${ }^{22}$ The practical ways by which this goal may be achieved, the Qur'an informs us, is by following in the footsteps of Prophet Muhammad: "Say, [O Muhammad], if you love God, follow me; God will love you and forgive your sins: God is most forgiving, most merciful."23 Viewed in this light, it is through following the role model of the Prophet that man will recognize that the true object of his love is God; this awareness will empower him to live in the presence of the Beloved.

Throughout the Risale-i Nur Nursi elucidates on reciprocity of love between God and man, as well as ways by which this mutual love is manifest and becomes apparent. He refers to the Prophetic tradition that "the one who knows himself knows God", as well as, the Qur'anic verse: "People, it is you who stand in need of God-God needs nothing and is worthy of all praise". 24 The critical task for man, he concludes, is to acknowledge his existential poverty and realize that his entire existence is completely dependent on God as both the Creator and Sustainer. This acknowledgment, which every human being is able to comprehend, along with man's innate love for himself and desire for continuation of his existence, will bring about the recognition that, indeed the only true object of love-the Beloved-is the Creator.

My Creator saved me from non-existence, which is eternal darkness, and gave me a beautiful world like this one. Then when the time comes for me to die, He will again save me from

20 For the English translation, see (Chittick 2013, p. 43).

21 The Qur'an: 33:72.

22 Al-Ghazālī discusses five causes and categories of love for God. See (Al-Ghazālī 2011, pp. 13-22).

3 The Qur'an, 3:31.

The Qur'an, 35:15. 
non-existence, which is eternal extinction, and from annihilation, and bestow on me in an eternal realm an everlasting and truly magnificent world. (Nursi 1992c, p. 91)

Recalling our discussion on the theology of divine names, it may be noted here that one of the descriptions of the name al-Latîf, Gentle, is that God's utmost gentleness towards humankind was to create them where they had no claim. The famous mystic and theologian of Persia, Ahmad ibn Manșūr Sam'ānī (d. 1140), confirms Nursi's remarks and comments on man's existential poverty in light of the meaning of al-Latîf.

Latîf means knowing and it also means beautiful doer. God says 'God is gentle to His servants' (42:19). Which beautiful doing is beyond the fact that you were in concealment of nonexistence, and He was taking care of your work with bounty and generosity? You were in the concealment of nonexistence, and He chose you out from the whole world ... He was tossing the secret hook of He loves them into the ocean of they love Him. ${ }^{25}$ (Sam'ānī 1391, p. 241)

Furthermore, an extension of self-love, one may argue, is man's love for everything else that he appears to own such as power, wisdom, knowledge, which in fact are samples of the divine names and, therefore, must be recognized as "other indicative" (ma'āni harfì), pointing to their original Source. In Nursian theology, humankind's intrinsic love for beauty, perfection, immorality, etc., reveals the inescapable force that attracts and invites human beings to recognize their love for the Source of perfection and beauty that stems from the One:

Man was created with an infinite innate love for the universe's Creator. For included in human nature are a love of beauty, an ardor for perfection, and passion for bestowal. His love increases proportionately to the degrees of beauty, perfection and bestowal, reaching the furthest degrees of ecstatic love. Since human nature has such an infinite capacity to love bestowal, beauty and perfection; and since universe's Creator possesses infinite sacred beauty, the certain existence of which is self-evidently established by His works to be seen in the universe; and since He possesses infinite holy perfection, the existence of which is necessarily proved by embroideries of His art apparent in beings; and since He is the owner of infinite bounties, the existence of which is certainly established by the infinite varieties of His bestowal and bounties to be observed in living creatures; these surely demand infinite love from man, who is the most comprehensive, the most needy, the most thoughtful and the most yearning of conscious beings. Indeed, all human beings are capable of infinite love for the All Glorious Creator, and in the face of His beauty, perfection, and bestowal, the Creator is more deserving of love than anyone. ${ }^{26}$ (Nursi 1992c, p. 90)

It should also be mentioned here, that in his disposition on the all-inclusive notion of love, Nursi frequently reminds his readers that much danger awaits man if he fails to recognize the Source of love. Moreover, as Turner points out, Nursi is very much aware of the 'misguided love' which can lead to spiritual perdition and advises his audience on how love for other than God may be reoriented, so that it can be directed at God (Turner 2013, p. 435).

That humankind must raise his awareness of the divine love ingrained in his inner being, fitra, and constantly remember that the only true object of love is his Lord is clear from the above passage of the Risale-i Nur. However, one may question the practicality of this argument at times when one is afflicted with a serious illness or other adversities. How is one to reconcile the love of God with the reality of the most difficult times that seem to be part and parcel of the human experience? The final section of the study will attempt to shed light on this question.

25 For the English translation, see (Chittick 2013, pp. 13-14).

26 Nursi seems to have been familiar with Ibn Sīnā's works and sometimes referred to him, for example in the Tenth Words, to substantiate his argument. Here we see he converges with Ibn Sīnā on the notion of an in-born love; see (Avicenna 1945, p. 5). 


\section{Trial and Tribulation in the Context of Divine Love: A Synergy}

As previously mentioned, al-Ghazāli's statement of "the best of all possible worlds" appeared at the center of Leibnitz's theodicy several centuries later in Europe (Leibniz 2007). Furthermore, throughout the history of philosophy of religion, other theodicies have developed whereby the philosophers and theologians discuss the 'Problem of Evil', and make a serious attempt to reconcile certain attributes of God and the fact of human suffering. ${ }^{27}$ However, it may be argued that theodicies, regardless of the level of their success, do not necessarily help the person who encounters a serious illness or other forms of adversity. Philosophical reflections notwithstanding ${ }^{28}$, it is the existential angle of human suffering that affects the ordinary believer who, in spite of a strong faith in an All-Loving God, is perplexed on how to come into terms with the realities of illness, financial difficulty, social injustice, or death of a loved one that either impacts him directly, or indirectly through others.

The notion of trial and tribulation, ibtila $\bar{a}$, and its multidimensional aspects, appears in the Qur'an as a central theme, and is portrayed with a positive connation (Rouzati 2015). Naturally, then, the mystical theological literature engages with the problem in a discussion that is, for the most part, presented in the context of divine love. According to al-Ghazālī, "God's love for man lies in His drawing him near ... God gives love to no one unless He afflicts him!" (Al-Ghazālī 2011, pp. 104-5). To this end, Maybudi, the Qur'anic exegete whom we quoted earlier, informs us that trial and tribulation is undisputable sings of divine love; those who are closest to the Beloved are more deserving of union, and therefore, will be afflicted more (Maybudī 1371, vol. I, p. 423).

As human beings we may come into contact with different forms of difficulties. Amongst the most perceptible adversities that every individual experiences during the course of his life are physical illnesses, and certainly Nursi's life was no exception. ${ }^{29}$ In an attempt to raise awareness to the 'actual role' that illness is meant to play in one's life, Nursi invokes thinking by what may seem to be a paradox at first glance: "Your illness is not a malady for you; it is a sort of cure" (Nursi 1992c, p. 266). Through this bold statement, Nursi invites the reader to reflect upon his illness, find its deeper meaning, and look forward to the positive results that await him. Progressively, he leads the reader to realize that life without adversities and trials is spent in thoughtlessness, goes by swiftly, and without producing valuable fruits.

It may be worth mentioning that John Hick, the well-known Christian philosopher of religion (d. 2012), seems to support Nursi when he explicates on the concept of 'the best of all possible worlds', and provokes thinking by asking "best for what purpose?" According to Hick, humankind is in the process of becoming the perfected being that God is seeking to create and, therefore, views human suffering in the role that it plays in the eventual outworking of that purpose (Hick 2007, pp. 253-61). Likewise, in Nursi's opinion, illness offers an invaluable opportunity to reflect on one's life, make necessary changes to live life in accordance with the goal of the Creator, to actualize its potentials and become God's vicegerent. To this end, Nursi asserts, "for you illness is good health, while for some of your peers good health is a sickness" (Nursi 1992c, p. 268).

Moreover, a hidden positive feature of illnesses, Nursi reminds his audience, is that it serves as a reminder about death—a somewhat forgotten fact—-that ultimately man will depart this world only to continue an eternal life in the hereafter while he is re-united with the Source of his existence. According to Nursi, illness suddenly lifts the veil from one's internal eye, and brings the forgotten reality of death to the forefront: "You are not immortal". By raising awareness about the reality of death, Nursi highlights the importance of being thankful to God for this opportunity rather than complaining about the illness. One is reminded of the famous dictum from one of most respected religious authorities of

27 See for example (Plantinga 1974; Adams and Merrihew 1994).

28 For instance, Ibn Sinnā deals with the notion of 'evil' and its ontology in his philosophy. See (Inati 2000).

29 Nursi experienced all sorts of adversities in various stages of his life. For a detailed biography on Nursi, see (Vahide and Ibrahim M. 2005) 
early Islam, Imam Zayn al-'Abidīn:" Oh, Allah, I don't know when to offer more thanks (shukr)—when you afflict me with illness, or when you bestow on me full health" (Sajjad 1998). Furthermore, in other parts of the Risale-i Nur, Nursi elucidates on the sickness of the heart, that which separates man from God, and identifies it as the true cause of human suffering. ${ }^{30}$

Fully cognizant of the fact that human beings generally do not possess perseverance at the time of illness or other adversities, Nursi's teachings seem to indicate a common thread with other mystic theologians. That is, to view the apparent undesirable circumstances as an opportunity to get to know the All-Loving God whose unrestricted love for His creation can be experienced if one is willing to see the reality beneath the surface of things. ${ }^{31}$

\section{Conclusions}

The overall notion of creation, as well as the Creator-creation relationship appears at the center of Qur'anic teaching and, therefore, constitutes a large portion of the Muslim intellectual literature from various perspectives. At the core of this debate is the concept of divine love and a loving relationship between an utterly transcendent Creator and human being as an infinite and mortal entity.

For the Muslim philosophers (falsifa), divine love loomed large on the horizon as a critical component within their ontological and cosmological worldview. From this perspective, the Necessary Being $(w \bar{a} j \bar{i} b$ al $w u j \bar{u} d)$ is characterized as pure love and perfect; His love is the Source of all that exists in the universe, and the reason that everything eventually finds its way back to its Source. Likewise, in the worldviews of the mystics, divine love was presented as a major constituent in the relationship of the loving God who created the best possible world — the perfect environment for mankind to flourish and become who he is.

On the other hand, while the theological (Kalām) discourse of early Muslim history emphasized certain attributes of God, such as power, wisdom, and knowledge, divine love, however, was not presented as a key element. Moreover, for the Ash'arite and Mu'tazilite schools of theology, the suggestion that God's relationship with human beings might be recognized as a mutual love relationship was viewed as nonconformity with the original path of Islamic tradition and, therefore, extremely controversial. However, when Abū Hāmid al-Ghazālī developed a methodical theory of love, grounded in the tradition of Islam and expressed in intelligible and rational terms, divine love emerged as a coherent and respectable discourse.

Said Nursi's magnum opus, Risale-i Nur, treats the notion of divine love comprehensibly. His engagement with the doctrine of love is unique and multidimensional. On the first level, it is intellectual, for it is articulated in terms of self-knowledge, which ultimately leads to knowledge of God. Still, on a deeper level, his approach is spiritual, as it aims to provoke nearness to God in general, and during adversities and difficult times in particular.

The wisdom behind the creation of the universe, therefore, lies in God's love for all that comes into existence through His creative command. Humankind's mission, as God's vicegerent on earth, is to realize the purpose of his creation, namely, to become the polished mirror in which the names and attributes of the Beloved is manifested. This will ultimately result in the actualization of tawhīd at its climax-there is nothing truly loving except the Loving.

Funding: This research received no external funding.

Conflicts of Interest: The author declares no conflict of interest.

30 For example, see (Nursi 1992d, p. 272).

31 For more on this, see (Rouzati 2018). 


\section{References}

Abrahamov, Binyamin. 2003. Divine Love in Islamic Mysticism. New York: Routledge.

Adams, Marilyn McCord, and Robert Merrihew, eds. 1994. The Problem of Evil. New York: Oxford University Press.

Al-Ghazālī, Abū Hāmid. 1377. Ihyā' 'ulūm al-dīn. Translated by Mohammad Khajawii. Tehran: Shirkat Intisharat Elmi va Farhangi.

Al-Ghazālī, Abū Hāmid. 1992. The Ninety-Nine Beautiful Names of God, al-Magṣad al-asnā fĩ sharh ma'ānī asmā' Allāh al-husnā. Translated by David B. Burrell. Cambridge: The Islamic Text Society.

Al-Ghazālī, Abū Hạāmid. 2011. Kitāb al-ṣabr wa' l-shukr', Patience and Thankfulness, Book XXXII of Ihyyā' 'ulūm al-dīn. Translated by Henry T. Littlejohn. Cambridge: Islamic Text Society.

Al-Ghazālī, Ahmad. 2013. Sawanih: Inspirations from the World of Pure Spirits. Translated by Nasrollah Pourjavady. New York: Routledge.

Al-Juwayni, Abu'l-Ma'ali ‘Abd al-Malik b. Muhammad. 2000. Kitab Al-Irshad Ila Qawati'Al-Adilla Fiusul Al-i'tiqad, A Guide to Conclusive Proofs for the Principles of Belief. Translated by Paul E. Walker. Lebanon: Garnet.

Anwar, Etin. 2003. 'Ibn Sina's Philosophical Theology of Love: A study of the Risalah fi al-'Ishg'. Islamic Studies 42: 331-45.

Avicenna. 1945. Risalah fi al-'Ishg, A Treatise on Love. Translated by Emil L. Fackenheim. Toronto: Mediaeval Studies, vol. 7, pp. 208-28.

Avicenna. 2005. The Metaphisics of the Healing (Shifa'). Translated by Michael E. Marmura. Utah: Brigham Young University Press.

Baker, Chris, ed. 2017. Uncontrolling Love: Essays Exploring the Love of God with Introuduction by Thomas Jay Oord. San Diego: Sacrasage Press.

Bell, Joseph Norment. 1979. Love Theory in Later Hanbalite Islam. Albany: State University of New York.

Brown, Jonathan A. C. 2009. Hadith, Muhammad's Legacy in the Medieval and Modern World. Oxford: One World.

Chittick, William C. 1989. Ibn al-'Arabī's Metaphysics of Imagination, The Sufi Path of Knowledge. Albany: SUNY.

Chittick, Murata. 1994. The Vision of Islam. St. Paul: Paragon House.

Chittick, William C. 2013. Divine Love, Islamic Literature and the Path to God. New Haven: Yale University Press.

Elkaisy-Friemuth, Maha. 2006. God and Humans in Islamic Thought, 'Abd al-Jabbar, Ibn Sina and al-Ghazali. New York: Routledge.

Hick, John. 2007. Evil and the God of Love. New York: Palgrave Macmillan.

Inati, Shams C. 2000. The Problem of Evil: Ibn Sina's Theodicy. Albany: State University of New York Press.

Keeler, Annabel. 2006. Sufi Hermeneutics-The Qur'an Commentary of Rashid Al-Din Maybudi. London: Oxford University Press.

Leibniz, Freiherr Von Gottfried. 2007. Thodicy: Essays on the Goodness of God, the Freedom of Man and the Origin of Evil. Translated by E. M. Huggard. Charleston: Bibliobazaar.

Lumbard, Joseph E. B. 2016. Ahmad Al-Ghazali, Rememberance, and the Methaphysics of Love. New York: State University of New York.

Maybudī, Abolfazl Rashid al-din. 1371. Kashf al-Asrar (Unveiling of Mysteries). Tehran: Amir Kabir.

Mulla Sadra Shirazi, Sadr al-Din. 1388. Al-Asfār, Al-Arb'a. Translated by Mohammad Khajawii. Tehran: Mola.

Nasr, Seyyed Hossein. 2006. Islamic Philosophy from its Origin to the Present. Albany: State University of New York Press.

Netton, Ian Richard. 1994. Allah Transcendent: Studies in the Structure and Semiotics of Islamic Philosophy, Theology, and Cosmology. London: Routledge.

Nursi, Bediuzzaman Said. 1992a. The Words. The Risale-i Nur Collection. Translated by Sukran Vahide. Istanbul: Sozler.

Nursi, Bediuzzaman Said. 1992b. The Letters. The Risale-i Nur Collection. Translated by Sukran Vahide. Istanbul: Sozler.

Nursi, Bediuzzaman Said. 1992c. The Flashes. The Risale-i Nur Collection. Translated by Sukran Vahide. Istanbul: Sozler.

Nursi, Bediuzzaman Said. 1992d. The Rays. The Risale-i Nur Collection. Translated by Sukran Vahide. Istanbul: Sozler. 
Oord, Thomas Jay. 2015. The Uncontrolling Love of God: An Open and Relational Account of Providence. Westmont: IVP Academic.

Ormsby, Eric L. 1984. Theodicy in Islamic Thought: Dispute Over Al-Ghazali's "Best of All Possible Worlds". Princeton: Princeton University Press.

Plantinga, Alvin. 1974. God, Freedom, and Evil. Cambridge: WM. B. Berdmans.

Rahman, Fazlur. 1975. The Philosophy of Mulla Sadra. Albany: State University of NY Press.

Rouzati, Nasrin. 2015. Trial and Tribulation in the Qur'an: A Mystical Theodicy. Berlin: Gerlach.

Rouzati, Nasrin. 2018. Evil and Human Suffering in Islamic Thought-Towards a Mystical Theodicy. Religions 9: 47. [CrossRef]

Rūmī, Jalāl al-Dīn. 2001. The Mathnawi of Jalaluddin Rumi. Translated by Reynold A. Nicholson. Cambridge: E.J.W. Gibb Memorial. First published 1926.

Rūmī, Jalāl al-Dīn. 1379. Diwan Shams Tabrizi. Tehran: Peyman.

Rūmī, Jalāl al-Dīn. 1957. Masnawi-ye Ma'navi. Tehran: Amir Kabir.

Sajjad, Imam Zayn al-'Abidīn. 1998. Al-Sahīfat Al-Sajjādiyya, The Psalms of Islam. Translated by William Chittick. New York: Oxford University Press, p. 658. (In English)

Sam'ānī, Aḥmad ibn Manșūr. 1391. Rawh al-arwāh fì sharh asmā' al-malik al-fattāh (Repose of the Spirtis:Explaining the Names of the All-Opening King-Mystical Interpretation of Divine Names). Tehran: Intisharat Elmi Farhangi.

Schimmel, Annemarie. 1975. Mystical Dimentions of Islam. Chapel Hill: The University of North Carolina Press.

Swedenborg, Emanuel. 2015. Divine Love and Wisdom. Original published 1772 in English. Translated by George Dole. West Chester: Swedneborg Foundation.

Tabatabai, Muhammad Hussain. 1367. Al-Mizan. Translated by Seyed M. Bagher Musavi-Hamedani. Qum: Daftar Intisharat Islami.

Turner, Colin. 2013. The Qur'an Revealed: A Critical Analysis of Said Nursi's Epistles of Light. Berlin: Gerlach Pess.

Vahide, Sukran, and Abu-Rabi' Ibrahim M., eds. 2005. Islam in Modern Turkey: An Intellectual Biography of Bediuzzaman Said Nuris. Albany: State University of New York Press.

Zamakhshari, Abul Qasim Mahmud. 1389. Al-Kashaf an Haga'ig Ghawamid Al-Tanzil Wa-Uyun Al-Aqawil fi Wujuh al-Tawi. Translated by Masud Ansari. Tehran: Dar al-Kitab al-Arabi, Beirut/Qoqnoos.

Publisher's Note: MDPI stays neutral with regard to jurisdictional claims in published maps and institutional affiliations.

(C) 2020 by the author. Licensee MDPI, Basel, Switzerland. This article is an open access article distributed under the terms and conditions of the Creative Commons Attribution (CC BY) license (http://creativecommons.org/licenses/by/4.0/). 